\title{
Organizational Commitment and Intension Turnover : Evidence from Star Hotel in Batam
}

\author{
Ngatemin \\ Akademi Pariwisata Medan \\ Medan, North Sumatera \\ email: ngatemin_ngn@yahoo.co.id
}

\author{
Rahmat Darmawan \\ Akademi Pariwisata Medan \\ Medan, North Sumatera \\ email: mawan69nonecanstopme@gmail.com
}

\begin{abstract}
This research aims to examine the direct and indirect effect of the Intension Turnover. The research approach used for this research is to analyze the research type explanations (explanatory/confirmatory research). In this study, the endogenous variable is organizational commitment and turnover intention, while being exogenous variables such as: Compensation, Motivation and Job Satisfaction. The population in this research is all employees that there are five-star hotel in the city of Batam from top level management - lower management. While samples taken in this study of 60 people with a random sampling technique. For secondary data collection is done by conducting a survey and study of literature from multiple sources that can be trusted and valid for primary data while data is collected using a questionnaire instruments. Data methods were analyzed with path analysis. The results showed that there was the influence of compensation on organizational commitment, no influence of job satisfaction on organizational commitment, no influence of work motivation on organizational commitment, there is no influence of compensation on turnover intention, there was no effect of job satisfaction on turnover intention, no influence of work motivation on turnover intention, there is no influence between organizational commitment to turnover intention, there is the influence of compensation, job satisfaction and work motivation on organizational commitment, no influence compensation, job satisfaction, work motivation and organizational commitment on turnover intention and no effect of compensation, job satisfaction and work motivation on turnover intention through the organization's commitment to star Hotel in the city of Batam Riau Islands Province.
\end{abstract}

Keywords : Compensation, Job Satisfaction, Motivation, Organizational Commitment and Turnover Intention

\section{INTRODUCTION}

Batam City that is part of the Riau Islands Province, has an area of land covering an area of $1,040 \mathrm{~km}^{2}$, or about 1.5 times the area of Singapore, while the total area reached 2,950 $\mathrm{km}^{2}$. Kota Batam tropical climate with average temperatures of 26 to 34 degrees Celsius. The economic growth of Batam is higher than the national economic growth rate make this area a mainstay for the driver of national economic growth and for the Riau Islands Province.
Various sectors of the economic drivers include the communications, electricity, water and gas, banking sector, the industrial sector and over the ship, trade and services sector is an economic pulse city of Batam, which is not only the public consumption Batam and Indonesia but also an export commodity for another country, The existence of economic activity in the city is also in order to boost employment and social welfare. As a city industry is a rapidly growing sector of the tourism industry of Batam city is also experiencing rapid growth, supported by facilities of hotels and resorts of international standard and the various tourist activities that are arranged in a calendar of events tourism, City of Batam provide comfort and satisfaction of domestic and foreign tourists when visit this city.

A. Literatur Review

Transfer of employees (employee turnover) is a phenomenon that often occurs in the hospitality industry (hospitality industry). Turnover is defined as the voluntary withdrawal (voluntary) or involuntary (involuntary) of the organization (Robbins, 1996). Woods and Macaulay (1989) that the high turnover in the hospitality industry can interfere with surgery, childbirth moral problems on employees who live, and also drives up the cost for recruitment, interviews, tests, checking references, the administrative costs of processing new hire, benefits, orientation, and the cost of lost opportunities because employees had to learn new skills. On the other hand Rousseau (1984) adds that the costs or losses on their turnover includes the direct costs associated with recruitment activities (among others, advertising costs, agency costs) and the cost of the search; indirect costs eg costs associated with training new employees; and loss of productivity by learning new employees. 
A strong commitment to make individuals more concerned with organizations rather than personal interests and seeks to make the organization better whereas low organizational commitment that will allow individuals to act for their own interests. Associated with commitment (Nouri and Parker, 1996; Mc.Clurg, 1999; Chong and Chong, 2002; Wentzel, 2002) states that organizational commitment can be psychological tools in running his organization to the achievement of expected performance. Cotton and Tuttle (1986) suggest individuals who have a high organizational commitment likely will not want to leave the organization even though there is a job offer elsewhere. This occurs because the individual who committed the organization to believe and accept the objectives and values of the organization, wants to always strive for the achievement of organizational goals and have a strong desire to remain a member of the organization (Porter et al. 1974; Mowday et al. 1979; Mowday et al. 1982). Mowday et al. (1982) describe the consequences of organizational commitment most predictable and most powerful is the level of behavior to move lower. Mathieu and Zajac (1990) states the organization's commitment relates to the presence, delays and switching behavior. Next, Porter et al. (1974) states that when an individual is not satisfied with his work, a high commitment to the organization will help to rule out such dissatisfaction in making the decision to continue participating in the organization. Low organizational commitment can also be triggered by dissatisfaction at work that impact the desire to move (turnover intention) which in turn is realized with the transfer of employees (employee turnover).

Job satisfaction or job satisfaction is an emotional state that is pleasant or unpleasant by which employees view their work (Handoko, 1992; 193). Job satisfaction is a bias on the feelings of employees towards work he is performing. Related to this is the job satisfaction will be seen in the attitude of workers to the job. Employees who feel satisfied with the work seen in employees who have a positive attitude towards the job at hand and the environment. Conversely, a disgruntled employee will act negatively toward work. In daily operations - the dissatisfaction of employees should be able to be detected by the company. According Muchinsky (1997), declare variables that can be used as an indication of declining job satisfaction is absenteeism, turnover, and job performance. In line with these opinions As'ad $(1995 ; 103)$ explains that the variables that can be used as an indication of declining job satisfaction is the high rate of absenteeism (absenteeism), the high exit-entry of employees (turnover), and decreased work productivity or employee performance (performance),

Compensation is everything received by employees as remuneration for their work, (Hani Handoko: 1993). Fringe benefits provided to employees' can take the form of money (financial) or other forms of nonmonetary (non-financial), such as in-service awards, promotions, and other activities. Every employee who works basically is to earn income or remuneration to meet their needs. All financial rewards received by the people through their employment relationship with the organization, (Bejo Siswanto: 2003), any form of payment or benefits granted to employees and arising from the employment of the employee (Dessler: 1997). According to Dessler (1997) Award Compensation can be classified into 3 types: 1) Payment of money directly (direct financial payment) in the form of salary, and intensive or bonus / commission. 2) Payment indirectly (indirect payment) in the form of benefits and insurance. 3) nonfinancial rewards (non-financial rewards), such as flexible work hours and prestigious office. Therefore, an employee will strive hard work and continued to show loyalty to the company if the company is to know and understand and be able to pay tribute to the work performance of employees in the form of compensation. With the provision of a satisfactory compensation it will be a good motivation for employees to improve performance and performance.

Motivation means a series of businesses to provide certain conditions, so that a person is willing and wanting to do something. (Mathis and Jakson, 2002: 13) Motivation is a desire in a person that causes the person to act. Individuals who have a positive motivation that will carry out the task in hand well. Another statement, Gibson et. al (1993: 94) motivation is a concept that we use when we describe the forces that work against or within 
the individual to initiate and direct behavior. Motivation is the process of trying to influence someone to do something to be desired, (Heidjachman and Husnan 2003: 197). A person who knowingly engaged in the activities of the organization usually has a specific background or motivation, (As'ad: 2003: 45), and thus the motivation that is in someone will realize a goal-directed behavior achieving satisfaction targets.

The previous research that tested about organizational commitment and turnover intention as the dependent variable with different independent variables, among others; Demicco and Reid, (1988) The desire to move someone closely associated with job satisfaction and organizational commitment, Gregson (1992), Poznanski \& Dennis (1997) to conduct additional testing through the summation relationship dependent variable, the causal relationship of organizational commitment and job satisfaction clearer than the causal relationship of job satisfaction and organizational commitment. Lum et al, (1998), Harif (2001) showed that job satisfaction has a direct impact on the desire to berpindak but indirect impact through organizational commitment. Pasewark \& Strawser (1996), Kelvin \& Indriantoro (1999) showed that the job satisfaction and organizational commitment and significant negative related to the desire to move. Concerned Lumbanraja (2007) research states that the individual characteristics of job satisfaction and organizational culture influence on organizational commitment with job satisfaction. Chun-Chang Lee et al (2012) research states that: 1) the relationship of coworkers and the working environment positive and significant impact on job satisfaction, 2) job satisfaction and salary level can indirectly affect the turnover intention through organizational commitment and salary levels high, 3) high job satisfaction and organizational commitment are high can affect the decrease in turnover intention.

\section{B. Methodology}

Relationships between variables that predicted in the study are described in the conceptual framework as follows:

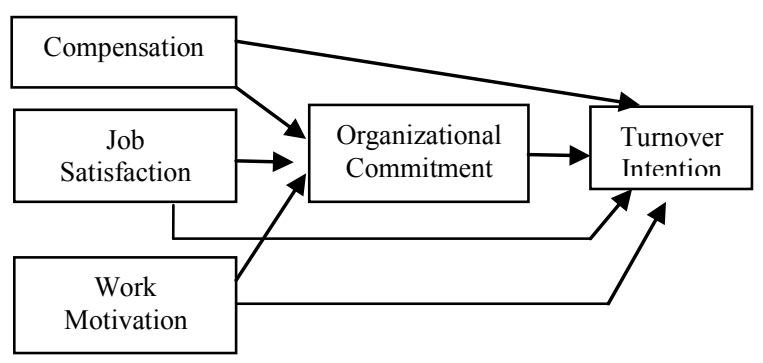

Figure 3.1

Antecedents of Organizational Commitment Model and its influence the intension Turnover

To test the effect of direct compensation, job satisfaction and motivation on organizational commitment, use equation modeling :

$$
\begin{aligned}
& \mathrm{X} 4=\mathrm{PX}_{4} \mathrm{X}_{1}+\mathrm{PX} 4 \mathrm{X}_{2}+\mathrm{PX} 4 \mathrm{X}_{3}+\epsilon \\
& \mathrm{Y}=\mathrm{PYX}_{1}+\mathrm{PYX}_{2}+\mathrm{PYX}_{3}+\mathrm{PYX}_{4}+\epsilon \\
& \mathrm{Y}=\text { Intention turnover } \\
& \mathrm{X} 1=\text { Compensation } \\
& \mathrm{X} 2=\text { Job Satisfaction } \\
& \mathrm{X} 3=\text { Work Motivation } \\
& \mathrm{X} 4=\text { Organization Commitment } \\
& \epsilon=\text { Error }
\end{aligned}
$$

\begin{tabular}{|c|c|c|c|c|c|}
\hline \multicolumn{6}{|c|}{ Coefficients ${ }^{\mathrm{a}}$} \\
\hline \multirow[b]{2}{*}{ Model } & \multicolumn{2}{|c|}{$\begin{array}{c}\text { Unstandardized } \\
\text { Coefficients }\end{array}$} & \multirow{2}{*}{$\begin{array}{c}\text { Standardized } \\
\text { Coefficients } \\
\text { Beta }\end{array}$} & \multirow[b]{2}{*}{$t$} & \multirow[b]{2}{*}{ Sig. } \\
\hline & B & Std. Error & & & \\
\hline $1 \quad$ (Constant) & .319 & 3.440 & & .093 & .926 \\
\hline Compensation & .269 & .128 & .232 & 2.098 & .040 \\
\hline Job Satisf. & .193 & .088 & .241 & 2.200 & .032 \\
\hline Motivation & .373 & .106 & .424 & 3.520 & .001 \\
\hline
\end{tabular}

\section{FINDINGS AND DISCUSSION}

The magnitude of the effect of variable compensation, job satisfaction and motivation on organizational commitment singly $t$ test was used. using numbers or Standardized Beta coefficients below:

Table 1. Cofficients

A. The Influences of Compensation, Job Satisfaction and Work Motivation Against Organizational Commitment.

- The Influence of Compensation Against Organizational Commitment

Based on the above table, the figure $\mathrm{t}$ research or thitung 2.098> 2.002 ttable so that $\mathrm{H} 0$ rejected and $\mathrm{Ha}$ accepted. That is, there is significant influence between the 
compensation to organizational commitment.

- The Influence of Job Satisfaction Against Organizational Commitment

Based on the above table, the figure $\mathrm{t}$ research or thitung 2,200>2,002 ttable so that $\mathrm{H} 0$ rejected and $\mathrm{Ha}$ accepted. That is, there is a significant effect between job satisfaction and organizational commitment.

- Influence of Work Motivation Against Organizational Commitment

Based on the above table, the figure $t$ research or thitung 3,520>2,002 so ttable $\mathrm{H} 0$ rejected and $\mathrm{Ha}$ accepted. That is, there is significant influence between motivation to work on organizational commitment.

From the coefficient table above shows the values of the regression coefficient is:
a. Coefficient $\mathrm{X} 1$ is $\mathrm{P} 1=0.232$
b. Coefficient $\mathrm{X} 2$ is $\mathrm{P} 2=0.241$
c. $\mathrm{X} 3$ coefficient is $\mathrm{P} 3=0.424$

As for seeing the effect of variable compensation, job satisfaction and motivation on organizational commitment is combined with the use of the calculations in the model summari, particularly the number of R-Square below:

Table 2. Correlation Coefficient

Model Summary
\begin{tabular}{|l|c|r|r|r|}
\hline Model & R & R Square & $\begin{array}{c}\text { Adjusted } \\
\text { R Square }\end{array}$ & $\begin{array}{r}\text { Std. Error of } \\
\text { the Estimate }\end{array}$ \\
\hline 1 & $.771^{1}$ & .594 & .572 & 1.49808 \\
\hline
\end{tabular}

a. Predictors: (C Motivation, Job Satisfaction, Compensation

Source: Research Results (Processed)

$\mathrm{R}$-square value above is amounting to 0.594 , indicating the contribution of variation of $\mathrm{X} 1, \mathrm{X} 2$ and $\mathrm{X} 3$ in influencing the variation of the $\mathrm{X} 4$ is equal to $59.40 \%$ of the figure are intentions that influence compensation, job satisfaction and work motivation on organisasisecara commitment together is $59.40 \%$, while the remaining $40.60 \%$ influenced by other factors. In other words, the variability of organizational commitment can be explained by using a variable compensation, job satisfaction and motivation by $59.40 \%$ amounting to $40.60 \%$ while the effect is caused by other variables outside the model. To determine the value of the residual path coefficients, namely:

$$
\mathrm{P}_{1}=\sqrt{1-r^{2}}=\sqrt{1-0,594}=0,637
$$

Based on the above analysis, it can be seen equation $\mathrm{Y}$ values in the path analysis diagram below:

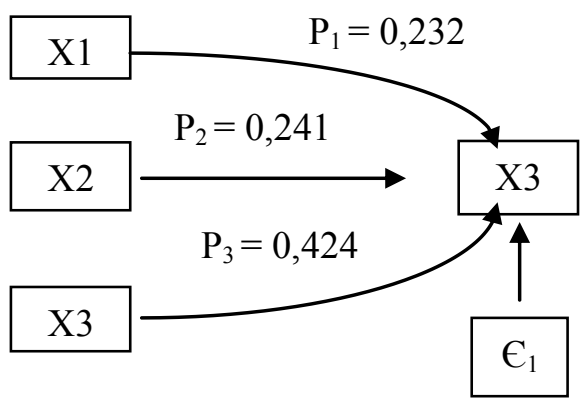

Figure 2. Diagram of Path Analysis Equation I

A. The Influences of Compensation, Job Satisfaction, Work Motivation and Organizational Commitment Against Turnover Intention.

The influences of compensation, job satisfaction, work motivation and organizational commitment to turnover intention partially, $t$ test was used, whereas to see the magnitude of the effect, use numbers or Standardized Beta Coeffecient below:

Table 3. Cofficients

\begin{tabular}{|c|c|c|c|c|c|}
\hline \multicolumn{6}{|c|}{ Coefficients $^{a}$} \\
\hline \multirow[b]{2}{*}{ Model } & \multicolumn{2}{|c|}{$\begin{array}{c}\text { Unstandardized } \\
\text { Coefficients } \\
\end{array}$} & \multirow{2}{*}{$\begin{array}{c}\begin{array}{c}\text { Standardized } \\
\text { Coefficients }\end{array} \\
\text { Beta }\end{array}$} & \multirow[b]{2}{*}{$t$} & \multirow[b]{2}{*}{ Sig. } \\
\hline & $B$ & Std. Error & & & \\
\hline (Constant) & 19.311 & 5.873 & & 3.288 & .002 \\
\hline Compensation & -204 & .227 & -.151 & -.899 & .372 \\
\hline Job Satisf. & .032 & 156 & .035 & .206 & .838 \\
\hline Motivation & .111 & .200 & .108 & .555 & .581 \\
\hline Commitment & .410 & .228 & .352 & 1.797 & .078 \\
\hline
\end{tabular}

Source: Research Kesults (rrocessed)

a. The Influence of Compensation Against Turnover Intention

Based on results of SPSS program calculations, research or figures obtained $t$ $\mathrm{t}_{\text {account }}-0.899>\mathrm{t}_{\text {table }}-2.002$ so that $\mathrm{Ha}$ is rejected and $\mathrm{H} 0$. That is, there is no significant effect between compensation for turnover intention.

b. The Influence of Job Satisfaction Against Turnover Intention

Based on results of SPSS program calculations, research or figures obtained $t$ 
$\mathrm{t}_{\text {account }} 0.206>2.002 \mathrm{t}_{\text {table }}$ that $\mathrm{H} 0$ rejected and $\mathrm{Ha}$ accepted. That is, there is no significant effect between job satisfaction on turnover intention.

c. The Influence of Work Motivation Against Turnover Intention

Based on results of SPSS program calculations, research or figures obtained $\mathrm{t}$ $\mathrm{t}_{\text {account }} 0.555<2.002 \mathrm{t}_{\text {table }}$ that $\mathrm{H} 0$ rejected and $\mathrm{Ha}$ accepted. That is, there was no significant effect of work motivation on turnover intention.

d. The Influence of Organizational Commitment Against Turnover
Intention

Based on results of SPSS program calculations, research or figures obtained $t$ $\mathrm{t}_{\text {account }} 1.797<2.002 \mathrm{t}_{\text {table }}$ that $\mathrm{H} 0$ rejected and $\mathrm{Ha}$ accepted. That is, there is no significant effect between organizational commitment to turnover intention.

From the coefficient table above shows the values of the regression coefficient is:
a. Coefficient X1 is P3 $=-0.151$
b. Coefficient $\mathrm{X} 2$ is $\mathrm{P} 4=0.035$
c. Coefficient $\mathrm{X} 3$ is p5 $=0.108$
d. Coefficient $\mathrm{X} 4$ is $\mathrm{p} 5=0.352$

As for seeing the effect of variable compensation, work motivation, job satisfaction and turnover intention on organizational commitment of employees in combination with the use of the calculations in the model summari, particularly R- Square numbers below:

Table 4 Correlation Coefficient Source: Research Results (Processed)

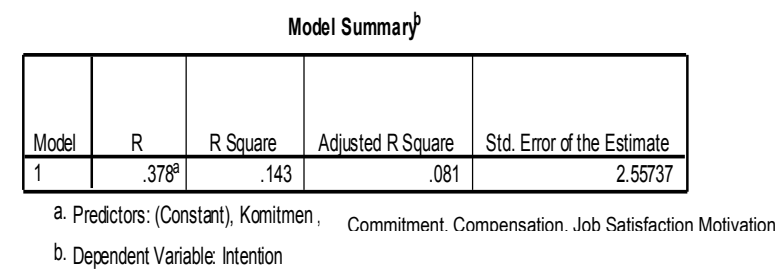

Source: Research Results (Processed)

The magnitude of the numerical value of $\mathrm{R}$-Square (r2) is 0.143 . The figure is used to see the effect of compensation, work motivation, job satisfaction and turnover intention on organizational commitment of employees by calculating the coefficient of determination (KD) using the following formula:

$$
\begin{aligned}
\mathrm{KD} & =\mathrm{r}^{2} \times 100 \% \\
& =0,143 \times 100 \% \\
& =14,30 \%
\end{aligned}
$$

These figures are intentions that influence compensation, job motivation, job satisfaction and organizational commitment to turnover intention together was $14.30 \%$, while the remaining $85.70 \%$ influenced by other factors. In other words, turnover intention variability that can be explained by using a variable compensation, work motivation, job satisfaction and organizational commitment amounted to $14.30 \%$ at $85.70 \%$ while the effect is caused by other variables outside the model.

Coefficient values in the above table can be used to determine the value of the residual path coefficients, namely:

$$
\mathrm{P} \epsilon_{1}=\sqrt{1-r^{2}}=\sqrt{1-0,143}=0,926
$$

Based on the above analysis, we can see the values of the equation II in the path analysis diagram below:

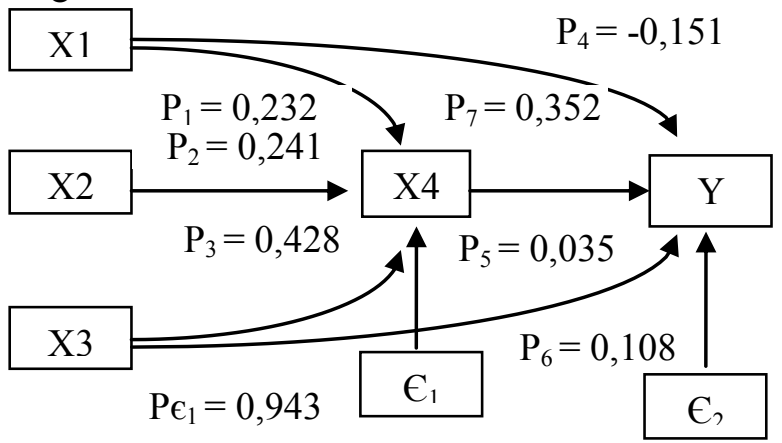

Figure 5-2. Path Analysis Diagram Equation II

\section{Direct Impact (Direct Effect)}

To calculate the direct effect is used the following formula:

a. Compensation variable effect on Organizational Commitment

$$
\mathrm{X} 1 \rightarrow \mathrm{X} 4=0.232
$$

b. Job satisfaction variable effect on Organizational Commitment

$$
\mathrm{X} 2 \rightarrow \mathrm{X} 4=0.241
$$

c. Work motivation variable influence on Organizational Commitment

$$
\mathrm{X} 3 \rightarrow \mathrm{X} 4=0.428
$$

d. Influence of Organizational Commitment variable to the Turnover Intention

$$
\mathrm{X} 4 \rightarrow \mathrm{Y}=0.352
$$

e. Compensation variable effect on Turnover Intention

$$
\mathrm{X} 1 \rightarrow \mathrm{Y}=-0.151
$$


f. Effect of Job Satisfaction on Intention variable Turnover

$$
\mathrm{X} 2 \rightarrow \mathrm{Y}=0,035
$$

g. Work motivation variable influence on Turnover Intention

$$
\mathrm{X} 3 \rightarrow \mathrm{Y}=0.108
$$

2. The indirect effect (Effect Inderect)

To calculate the indirect effect, use the following formula:

a. Compensation variable effect on Turnover Intention through Organizational Commitment

$\mathrm{X} 1 \rightarrow \mathrm{X} 4 \rightarrow \mathrm{Y}=(0.232 \times 0.352)=0.081664$

b. Job satisfaction variable effect on Turnover Intention through Organizational Commitment

$X_{2} \rightarrow X_{4} \rightarrow Y=(0,241 \times 0,352)=0.084832$

c.Work motivation variable influence on Organizational Commitment with Turnover Intention

$X_{3} \rightarrow X_{4} \rightarrow Y=(0,428 \times 0,352)=0.150656$ Judging from the effects of direct and indirect influence over and structural similarities to known pathways analysis in this study, namely:

Equation 1.

$$
\mathrm{X}_{4}=0,232 \mathrm{X}_{1}+0,241 \mathrm{X}_{2}+0,428 \mathrm{X}_{3}+\epsilon_{1}
$$

Equation 2.

$\mathrm{Y}=-0,151 \mathrm{X}_{1}+0,035 \mathrm{X}_{2}+0,108 \mathrm{X}_{3}+0,352$ $\mathrm{X}_{4}+\mathrm{C}_{1}$

\section{CONCLUSIONS AND SUGGESTION}

A. Conclusion

1. There is the influence of the compensation to the organization's commitment to star hotel in the city of Batam Riau Islands Province.

2. There is influence between job satisfaction and organizational commitment to the star hotel in the city of Batam Riau Islands Province.

3. There is the influence of work motivation on the organization's commitment to star hotel in the city of Batam Riau Islands Province.

4. Simultaneously there is influence between compensation, job satisfaction and motivation are significant to the organization's commitment to star hotel in the city of Batam Riau Islands Province.

5. In a direct effect between compensation, job satisfaction and motivation no significant effect on turnover intention on a star hotel in the city of Batam Riau Islands Province.

6.Simultaneously the influence of compensation, job satisfaction, motivation and organizational commitment turnover intention is not significant to the star hotel in the city of Batam Riau Islands Province.

7. Indirectly significant difference between the compensation, job satisfaction and work motivation on turnover intention through the organization's commitment to the star hotel in the city of Batam Riau Islands Province.

\section{B. Suggestion}

1.For the star hotel in the city of Batam Riau Islands Province results of this study should be taken into consideration to improve the organizational commitment of employees. The results of this study indicate a positive value, which means that if the compensation, job satisfaction and motivation improved the organizational commitment of employees also increased. So we need some decisions to increase organizational commitment of employees better so that later the expected performance can be achieved.

2.In order to increase motivation and commitment of employees organisasin then the star hotel in the city of Batam Riau Islands Province is expected to increase the compensation given.

3.Compensation, job satisfaction and motivation is an important part in improving organizational commitment of employees. Therefore, to increase employees' organizational commitment star hotel in the city of Batam Riau Islands province should pay attention to three aspects.

\section{BIBLIOGRAPHY}

1) As'ad M. 1995. Psikologi Industri. Yogyakarta: Liberti

2) _2003, Psikologi Industri : Seri Sumber Daya Manusia, Yogyakarta: Liberty

3) Bejo, Siswanto. (2003). Manajemen Tenaga Kerja Indonesia Pendekatan Administratif Dan Operasional. Jakarta: PT Bumi Aksara.

4) Chang, S.C. and Lee, M.S. 2008. The Linkage between Knowledge Accumulation anability and 
Organizational Innovation. Journal of Knowledge Management, XII (1): 3-20.

5) Cong, Vincent K. \& Kar Ming Chong, 2002. iBudget Goal Commitment and Informational Effects of Budget Participation on Performance, A Structural Equation Modeling Approachî. Journal of Accounting Research. pp. 65-68.

6) Cotton, J., \& Tuttle, J. (1986). Employee turnover : A meta-analysis and review with implications for research. Academy of Management Review,11 (1), 5570Demicco and Reid, (1988)

7) Dessler, Gary., (1997), Manajemen Sumber Daya Manusia, PT. Prenhallindo, Jakarta

8) DeMicco, Frederick. J., \& Reid, R. D. 1988. Older Workers: A Hiring Resources for The Hospitality Industry. Cornell Hotel and Restaurant Administration Quartely, May, pp. 56-62.

9) Gibson James L., Ivancevich John M., Donnelly James H, 1993. Organisasi, Perilaku, Struktur, Proses, Jilid 2, Edisi ke 2, Penerbit Erlangga, Jakarta

10) Gregson, T., 1992, "An Investigate of The Causal Ordering of Job Satisfaction and Organizational Commitment in Turnover Models in Accounting." Behavioral Research in Accounting, 4

11) Handoko, Hani. 1993. Penilaian Kinerja. Jakarta: Ghalia Indonesia.

12) Handoko, Martin,1992; 193, Motivasi Daya Penggerak Tingkah Laku, Jakarta : Rineka Cipta

13) Heidjachman dan Husnan. S., 2002, Manajemen Personalia, BPFE, Yogyakarta

14) Indriantoro, Nur dan Bambang Supomo. 1999. Metodologi Penelitian Bisnis untuk Akuntansi dan Manajemen. Edisi pertama. BPFE-Yogyakarta.

15) Lum L, Kervin J, and Clark K. (1998). Explaining nursing turnover intent: Job satisfaction, pay satisfaction or organizational commitment. Journal of Organizational Behavior, 24, 543- 565.

16) Lumbanraja, Prihatin, 2007,’Pengaruh Karakteristik Individu, Gaya Kepemimpinan dan Budaya Organisasi Terhadap Kepuasan Kerja dan Komitmen Organisasi", Program Pascasarjana Fakultas Ekonomi, Universitas Brawijaya Malang
17) Luthans, Fred, 2006, Perilaku Organisasi, Edisi kesepuluh, Penerbit Andi Offset.

18) Mathieu, J. E., \& Zajac, D.M. (1990) A review and meta analysis of the antecedents, correlates, consequences of organizational commitment. Psychological bulletin. 108, 171-194.

19) Mathis, dan Jackson, 2002, Manajemen Sumber Daya Manusia, Edisi pertama, Cetakan Pertama, Yogyakarta : Salemba Empat Mc.Clurg, 1999;

20) Mowday et al. 1982. "Employee Organization Linkages: The Psychology of Commitment, Absenteeism, and Turnover". San Diego. C.A.: Academic Press.

21) Mowday, R.T., Porter LW., dan Steers, R.M., 1979, Employee-Organizational Linkages : The Psychology Of Commitment, Absenteeism And Turnover: Academic Press, New York.

22) Muchinsky, P.M. (1997). Psychology Applied to Work (5th. Ed). USA : Brooks/Cole Publishing, Co.

23) Nouri, H. dan R. J. Parker. 1996. "The Effect of Organizational Commitment on Relation Between Budgetary Participation and Budgetary Slack". Behavior Research in Accounting 8. pp. 74-89.

24) Pasewark, W.R., at al, 1996, Determinants and Outcomes Associatedwith Job Insecurity an A Professional Accounting Environment, Behavioral Research in Accounting, Vol.8, pp. The $91-113$.

25) Porter, L.W., at al, 1974, Organization Commitment, Job Satisfaction and Turnover among Psychiatric Tecniciants, Journal Applied Psychology, Vol. 59, October, pp.603-609.

26) Poznanski; Peter J \& Blinc, Dennis M. 1997. Using Structural Equation Modeling to Investigate The Causal Ordering of Job Satisfaction and Organizational Commitment Among Staf Accounting. Behaviour Research in Accounting. Vol 9.

27) Robbins, S.P., (1996), Perilaku Organisasi,Edisi 12. Jakarta : Salemba Empat.

28) Wentzel, Kristin. 2002. "The Influence of fairness Perceptions and Goal Commitment on Managers' Performance in a Budget Setting", Behavioural Research in Accounting, Vol.14, pp. 247271 
29) Woods, Robert H and Macaulay, James F, 1989, R for Turnover: Retention Program that Work, Cornell Hotel and Restaurant Administration Quarterly, May,pp.78 - 90. 